\title{
Ewa BieńKowsKa
}

\author{
Warszawa
}

\section{WZAJEMNE UZNAWANIE ŚRODKÓW OCHRONY W SPRAWACH CYWILNYCH}

\section{WPROWADZENIE}

W ciągu ostatnich trzech lat Unia Europejska znacząco zintensyfikowała działania na rzecz wzmocnienia pozycji ofiar przestępstw. Jest to efektem wdrożenia - przyjętego przez Radę Europejską na lata 2010-2014 - programu sztokholmskiego ${ }^{1}$ zgodnie z planem opracowanym przez Komisję Europejską ${ }^{2}$. Pierwszoplanową rolę odgrywa w tym nurcie dyrektywa Parlamentu Europejskiego i Rady 2012/29/ UE z dnia 25 października 2012 r. ustanawiająca normy minimalne w zakresie praw, wsparcia i ochrony ofiar przestępstw oraz zastępująca decyzję ramową Rady 2001/220/WSiSW³. Dyrektywę tę uzupełnia najnowszy dokument poświęcony tej problematyce, jakim jest

\footnotetext{
1 Program sztokholmski - Otwarta i bezpieczna Europa dla dobra i ochrony obywateli (2010/C 115/01), Dz.Urz.UE C 115 z 4.5.2010, s. 1.

2 Komunikat Komisji do Parlamentu Europejskiego, Rady, Europejskiego Komitetu Ekonomiczno-Społecznego i Komitetu Regionów - Przestrzeń wolności, bezpieczeństwa i sprawiedliwości dla europejskich obywateli. Plan działań służących realizacji programu sztokholmskiego, Komisja Europejska, Bruksela, dnia 20.4.2010, $\operatorname{COM}(2010) 171$ wersja ostateczna na stronie: http://eur-lex.europa.eu/LexUriServ/ LexUriServ.do?uri=COM:2010:0171;FIN:PL:PDF

3 Dz.Urz.UE L 315 z 14.11.2012, s. 57; szerzej E BIEŃKowsKa, Ofiary przestępstw w postępowaniu karnym - nowe standardy Unii Europejskiej, «PiP» 71.4/2014, s. 58 i n.
} 
rozporządzenie Parlamentu Europejskiego i Rady (UE) nr 606/2013 z dnia 12 czerwca 2013 r. w sprawie wzajemnego uznawania środków ochrony w sprawach cywilnych ${ }^{4}$. Weszło ono w życie w dniu 19 lipca 2013 r., a ma być stosowane przez państwa członkowskie od dnia 11 stycznia 2015 r. w odniesieniu do środków ochrony orzeczonych w tym dniu i po tej dacie bez względu na to, kiedy zostało wszczęte postępowanie (art. 22). Zasługuje więc na baczną uwagę w Polsce jako unijnym państwie członkowskim.

Podstawą prawną rozporządzenia jest art. 81 ust. 2 lit. a), e) i f) Traktatu o funkcjonowaniu Unii Europejskiej ${ }^{5}$ (TFUE). W myśl tego przepisu - dla celów rozwijania współpracy sądowej w sprawach cywilnych, które mają skutki o charakterze transgranicznym (art. 81 ust. 1 TFUE) - „Parlament Europejski i Rada, stanowiąc zgodnie ze zwykłą procedurą prawodawczą, przyjmują, w szczególności, jeżeli jest to niezbędne dla prawidłowego funkcjonowania rynku wewnętrznego, środki mające na celu zapewnienie: a) wzajemnego uznawania i wykonywania przez Państwa Członkowskie orzeczeń sądowych i pozasądowych; ... e) skutecznego dostępu do wymiaru sprawiedliwości; f) usuwania przeszkód utrudniających prawidłowy przebieg procedur cywilnych, wspierając w razie potrzeby zgodność zasad procedur cywilnych mających zastosowanie w Państwach Członkowskich...".

Stosownie do pkt 5 Preambuty rozporządzenia dla osiągnięcia celu „W postaci swobodnego przepływu środków ochrony niezbędne i stosowne jest, aby zasady regulujące uznawanie oraz, w stosownych przypadkach, wykonywanie środków ochrony zostały uregulowane unijnym aktem prawnym, który będzie wiążący i bezpośrednio stosowany". Aktem takim jest rozporządzenie, które - inaczej niż dyrektywa wiążąca każde państwo członkowskie co do rezultatu, jaki ma zostać osiągnięty, ale pozostawiająca organom krajowym swobodę w wyborze formy i środków (art. 288 akapit 3 TFUE) - „ma zasięg ogólny. Wiąże w całości i jest bezpośrednio stosowane we wszystkich

4 Dz.Urz.UE L 181 z 29.6.2013, s. 4; zob. też J. Pisuliński (wybór i wprowadzenie), Europejskie prawo cywilne, Warszawa 2013, s. 904 i n.

5 Wersja skonsolidowana Dz.Urz.UE C 326 z 26.10.2012, s. 47. 
Państwach Członkowskich" (art. 288 akapit 2 TFUE), co podkreślono również w ostatnim zdaniu rozporządzenia. Podstawowa różnica pomiędzy dwoma wymienionymi aktami prawnymi sprowadza się zatem do tego, że o ile dyrektywa wymaga implementacji do wewnętrznych systemów prawnych poszczególnych państw członkowskich, o tyle rozporządzenie - nie .

Głównym zadaniem omawianego dokumentu jest ustanowienie przepisów dotyczących ,prostego i szybkiego mechanizmu uznawania środków ochrony wydanych $\mathrm{w}$ państwie członkowskim w sprawach cywilnych" (art. 1). Odnosi się on wyłącznie do spraw transgranicznych, czyli takich, w których o uznanie środka ochrony przyznanego w jednym państwie członkowskim występuje się w innym (art. 2 pkt 2 zd. 2).

Wskazano (pkt 6 Preambuly), że rozporządzenie dotyczy ,środków ochrony wydanych w celu ochrony osoby w przypadku, gdy istnieją poważne powody, aby uznać, że jej życie, integralność fizyczna lub psychiczna, wolność osobista, bezpieczeństwo lub integralność seksualna są zagrożone, na przykład w celu zapobieżenia wszelkim formom przemocy uwarunkowanej płcią lub przemocy w bliskich związkach, takim jak przemoc fizyczna, napastowanie, przemoc seksualna, nękanie, zastraszanie lub innym formom przymusu pośredniego. ... rozporządzenie ma zastosowanie do wszystkich ofiar, niezależnie od tego, czy są one ofiarami przemocy uwarunkowanej płcią, czy też nie". Tak więc, jego celem jest zapewnienie w sytuacjach transgranicznych ochrony określonych kategoriom ofiar przemocy.

Zgodnie z art. 2 pkt 3 nie odnosi się ono do środków ochrony uwzględnionych w rozporządzeniu Rady (WE) nr 2201/2003 z dnia 27 listopada 2003 r. dotyczącym jurysdykcji oraz uznawania i wykonywania orzeczeń w sprawach małżeńskich oraz w sprawach dotyczących odpowiedzialności rodzicielskiej, uchylającym rozporządzenie (WE) nr 1347/20007. Nie ma ono również zastosowania do środków ochrony orzeczonych w sprawach karnych (pkt 9 zd. 3 Preambuty).

\footnotetext{
6 Por. bliżej m. in. A. Wentkowska, [w:] J. Barcik, A. Wentkowska, Prawo Unii Europejskiej po Traktacie z Lizbony, Warszawa 2011, s. 179 i n.

7 Dz.Urz.UE L 338 z 23.12.2003, s. 1 (w brzmieniu nadanym sprost., Dz.Urz. L 70 z 14.3.2009, s. 19); też [w:] J. Pisuliński, op. cit., s. 623 i n.
} 
Wzajemnego uznawania tych ostatnich dotyczy odrębny akt prawny, a mianowicie dyrektywa Parlamentu Europejskiego i Rady 2011/99/ UE z dnia 13 grudnia 2011 r. w sprawie europejskiego nakazu ochro$n y^{8}$. W intencji Komisji Europejskiej, która dołączyła do pakietu legislacyjnego z dnia 18 maja 2011 r. projekt rozporządzenia ${ }^{9}$, miało ono uzupełniać inicjatywę 12 państw członkowskich z września 2009 r. dotyczącą przyjęcia tej dyrektywy ${ }^{10}$. Zapewnieniu wzajemnego uznawania środków ochrony o charakterze karnym powinna bowiem towarzyszyć analogiczna możliwość w odniesieniu do środków tego rodzaju orzeczonych w sprawach cywilnych.

Zatrzymajmy się na moment przy dyrektywie 2011/99/UE, ponieważ - z uwagi na swój przedmiot - jest aktem prawnym ważnym także $\mathrm{z}$ punktu widzenia tematyki tego opracowania. Weszła ona w życie z dniem 10 stycznia 2012 r. (art. 24), a powinna zostać wdrożona przez państwa członkowskie do dnia 11 stycznia 2015 r. (art. 21 ust. 1) ${ }^{11}$, a więc w takim samym terminie, jaki inicjuje stosowanie rozporządzenia $\mathrm{nr}$ 606/2013.

Wprowadzony dyrektywą 2011/99/UE europejski nakaz ochrony (ENO) ma zapewniać kontynuowanie w każdym z państw unijnych ochrony ofiar przestępstw gwarantowanej im karnoprawnymi środkami orzeczonymi w jednym z nich. Podkreślono (pkt 9 Preambuty), że „dyrektywa ma zastosowanie do środków ochrony, których szczególnym

8 Dz.Urz.UE L 338 z 21.12.2011, s. 2.

9 Por. Wniosek. Rozporządzenie Parlamentu Europejskiego i Rady w sprawie wzajemnego uznawania środków ochrony w sprawach cywilnych, COM(2011)276 wersja ostateczna na stronie: http://eur-lex.europa.eu/LexUriServ/LexUriServ.do?uri$=$ COM:2011:0276:FIN:PL:PDF, s. 2-3.

${ }_{10}$ Por. Inicjatywa Królestwa Belgii, Republiki Bułgarii, Republiki Estońskiej, Królestwa Hiszpanii, Republiki Francuskiej, Republiki Włoskiej, Republiki Węgierskiej, Rzeczpospolitej Polskiej, Republiki Portugalskiej, Rumunii, Republiki Finlandii, Królestwa Szwecji w sprawie przyjęcia dyrektywy Parlamentu Europejskiego i Rady w sprawie europejskiego nakazu ochrony (2010/C 69/02), Dz.Urz.UE C 69 z 18.3.2010, s. 5.

11 Wdrożenie dyrektywy 2011/99/UE do polskiego systemu prawnego przewiduje rządowy projekt z dnia 13 marca 2014 r. ustawy o ochronie pokrzywdzonego i świadka, na stronie Rządowego Centrum Legislacji (druk nr UC118). 
celem jest ochrona danej osoby przed czynem zabronionym innej osoby, mogącym w jakikolwiek sposób zagrozić jej życiu lub nietykalności fizycznej, psychicznej czy seksualnej, np. poprzez uniemożliwienie wszelkich form molestowania, czy jej godności lub wolności osobistej, np. poprzez uniemożliwienie uprowadzenia, nękania i innych form przymusu pośredniego, oraz które mają na celu zapobieganie nowym czynom zabronionym lub ograniczenie skutków wcześniejszych czynów zabronionych. ... dyrektywa ma zastosowanie do wszystkich ofiar, a nie tylko do ofiar przemocy uwarunkowanej płcią, z uwzględnieniem specyfiki każdego rodzaju przestępstwa”. Jest to zatem ta sama grupa ofiar, którą ma na uwadze omawiane rozporządzenie.

Wydanie i uznanie ENO może nastąpić wyłącznie w przypadku zastosowania ściśle określonych zakazów lub ograniczeń, jakimi - w myśl art. 5 dyrektywy - są: zakaz przebywania w określonych miejscach, miejscowościach lub na określonych obszarach, gdzie mieszka lub które odwiedza ofiara; zakaz lub ograniczenie wszelkich form kontaktowania się z nią, w tym telefonicznego, elektronicznego, korespondencyjnego, faksowego lub innego; bądź też zakaz lub ograniczenie możliwości zbliżania się do ofiary na odległość mniejszą niż zostało to wyznaczone. Warunkiem, który musi zostać spełniony jednocześnie, jest, aby ofiara planowała się udać lub już przebywała w innym państwie członkowskim niż to, w którym zastosowano zakaz lub ograniczenie (art. 6 ust. 1 zd. 1). O możliwości ubiegania się o ENO ofiara musi zostać powiadomiona przez organ orzekający określony lub określone zakazy bądź ograniczenia (art. 6 ust. 5), co jest ważne, ponieważ z wnioskiem o jego wydanie może wystąpić tylko ona (art. 6 ust. 2).

Funkcjonowanie ENO zależy od tego, czy unormowania wewnętrzne poszczególnych państw członkowskich przewidują wymienione w art. 5 dyrektywy bądź przynajmniej zbliżone do nich zakazy lub ograniczenia. Dyrektywa nie zobowiązuje jednak - w razie braku takich regulacji - do ich wprowadzenia do krajowych systemów prawa karnego, jak również do dostosowania już istniejących ,na potrzeby wykonywania" ENO (pkt 8 Preambuty). Dodać ponadto trzeba, że przyznanie ENO nie jest obligatoryjne, bowiem przy podejmowaniu 
decyzji brane są pod uwagę także takie czynniki, jak w szczególności długość pobytu ofiary w innym państwie lub zasadność zapewnienia jej w tym państwie ochrony (art. 6 ust. $1 \mathrm{zd}$. 2). Wszystko to sprawia, że instrument ten może okazać się w praktyce zarówno niełatwo dostępny, jak i mało skuteczny ${ }^{12}$.

Przyjrzyjmy się w tym kontekście unormowaniom rozporządzenia: co gwarantują one w zakresie ochrony ofiarom korzystającym z prawa do swobodnego przemieszczania się w obrębie UE? Rozpocznijmy od definicji pojęć występujących w tym akcie prawnym.

\section{DefiniCJE}

$\mathrm{W}$ art. 3 rozporządzenia sprecyzowano sześć podstawowych terminów, a mianowicie: środek ochrony; osoba objęta ochroną; osoba stwarzająca zagrożenie; organ wydający środek ochrony; państwo członkowskie wydania oraz państwo członkowskie, do którego kierowany jest wniosek.

Najważniejszą definicją jest definicja pojęcia „środek ochrony”. Jego ujęcie przesądza bowiem o zakresie wzajemnego uznawania, czyli o zakresie chronienia ofiar w sytuacjach transgranicznych. Jest nim (pkt 1), ,każda decyzja - niezależnie od jej nazwy - wydana przez organ wydający państwa członkowskiego wydania zgodnie z jego prawem krajowym, nakładająca na osobę stwarzającą zagrożenie jeden lub kilka spośród następujących obowiązków w celu ochrony innej osoby, której integralność fizyczna lub psychiczna może być zagrożona: a) zakaz lub ograniczenie wstępu do miejsca, w którym osoba objęta ochroną zamieszkuje, pracuje lub które regularnie odwiedza lub w którym regularnie przebywa; b) zakaz lub uregulowanie wszelkich form kontaktu z osobą objętą ochroną, w tym za pośrednictwem telefonu, poczty elektronicznej lub zwykłej, faksu lub innych środków; c) zakaz lub ograniczenie zbliżania się na określoną odległość do osoby

12 Szerzej E. BIEŃKowsKA, Europejski nakaz ochrony - istota i znaczenie, «Zeszyty Prawnicze» 12.4/2012, s. 151 i n.; por. też Z. BARwINA, Zasada wzajemnego uznawania w sprawach karnych, Warszawa 2012, s. 123 i n. 
objętej ochroną”. Wyjaśniono zarazem, że przy ocenie danego środka ochrony jako cywilnego nie należy kierować się cywilnym, administracyjnym bądź karnym charakterem wydającego go organu (pkt 10 zd. 2 Preambuły). Należy podkreślić, że objęte rozporządzeniem środki ochrony są analogiczne do zakazów i ograniczeń, które mogą być podstawą wydania i uznania ENO.

Warto dodać, że w rozporządzeniu nie została uwzględniona propozycja Komisji, aby dotyczyło ono jeszcze jednego środka ochrony, a mianowicie decyzji przydzielającej osobie objętej ochroną wyłączne korzystanie z wspólnego mieszkania (art. 2 lit. a) (iv) projektu rozporządzenia). Nie są znane motywy, z powodu których zrezygnowano z objęcia rozporządzeniem tego środka ochrony. Być może nie bez znaczenia było to, że nie ma on swojego odpowiednika wśród zakazów i ograniczeń pozwalających na ubieganie się o ENO.

„Osobą objętą ochroną” (pkt 2) jest „osoba fizyczna, która podlega ochronie udzielonej na mocy środka ochrony". W opracowaniu tym niekiedy zamiennie posługuję się co do niej terminem „ofiara”. Jest to w pełni uprawnione, ponieważ - jak wskazano w pkt 8 zd. 2 Preambuły rozporządzenia - „Fakt, że dana osoba jest przedmiotem środka ochrony wydanego w sprawach cywilnych, nie wyklucza możliwości określenia tej osoby jako „ofiary” na mocy dyrektywy 2012/29/UE”.

W myśl art. 2 ust. 1 lit. a) tego ostatniego aktu prawnego ofiarą jest „osoba fizyczna, która doznała szkody, w tym krzywdy fizycznej, psychicznej, moralnej lub emocjonalnej lub straty majątkowej, bezpośrednio spowodowanej przestępstwem”, jak również „członkowie rodziny osoby, której śmierć była bezpośrednim skutkiem przestępstwa, jeżeli doznali oni szkody w wyniku śmierci tej osoby”. Osób objętych ochroną, o których jest mowa w rozporządzeniu, dotyczy w związku z tym - jak podkreślono w pkt 7 Preambuly - również to, że na mocy dyrektywy 2012/29/UE powinny one otrzymywać odpowiednie informacje i wsparcie.

Z kolei „osoba stwarzająca zagrożenie” (pkt 3) to „osoba fizyczna, na którą nałożono jeden lub kilka obowiązków" spośród określonych w pkt 1 art. 3 rozporządzenia, które już zostały wymienione. 
„Organem wydającym środek ochrony” (pkt 4) jest „każdy organ wymiaru sprawiedliwości lub każdy inny organ wyznaczony przez państwo członkowskie jako właściwy w sprawach należących do zakresu stosowania ... rozporządzenia, o ile taki inny organ daje stronom gwarancje w odniesieniu do bezstronności i o ile jego decyzje dotyczące środków ochrony mogą na mocy prawa państwa członkowskiego, w którym funkcjonuje, być przedmiotem odwołania do organu sądowego oraz mają podobną moc i podobne skutki jak orzeczenie organu sądowego w takiej samej sprawie". W pkt 13. Preambuty dodano, że po to, aby uwzględnić „fakt, że w państwach członkowskich środki ochrony w sprawach cywilnych - inaczej niż w przypadku innych obszarów współpracy sądowej - są wydawane przez organy różnego rodzaju, ... rozporządzenie powinno mieć zastosowanie do decyzji zarówno organów sądowych, jak i organów administracyjnych, o ile te ostatnie zapewniają gwarancje, zwłaszcza w odniesieniu do ich bezstronności i do prawa stron do odwołania się do sądu. W żadnym wypadku za organy wydające $\mathrm{w}$ rozumieniu ... rozporządzenia nie powinny być uznawane organy policyjne”.

„Państwo członkowskie wydania” (pkt 5) to „państwo członkowskie, w którym zostaje wydany środek ochrony”. Określenie ,państwo członkowskie, do którego kierowany jest wniosek" (pkt 6) odnosi się natomiast do tego państwa, „w którym występuje się o uznanie oraz, w stosownych przypadkach, wykonanie środka ochrony".

\section{UZNAWANIE I WYKONYWANIE ŚRODKÓW OCHRONY}

\subsection{Ogólne zasady}

Jak zastrzeżono w pkt 18 Preambuty, ,rozporządzenie powinno dotyczyć jedynie uznawania obowiązku nałożonego $\mathrm{w}$ ramach środka ochrony. Nie powinno ono regulować postępowań służących wdrażaniu lub wykonywaniu środka ochrony, ani sankcji, które mogłyby zostać nałożone w przypadku naruszenia w państwie członkowskim, do którego kierowany jest wniosek, obowiązku orzeczonego w ramach 
środka ochrony. Kwestie te powinny być regulowane w prawie tego państwa członkowskiego. Jednak zgodnie z zasadami ogólnymi prawa Unii, a w szczególności z zasadą wzajemnego uznawania, państwa członkowskie mają zapewnić, aby środki ochrony uznane na mocy ... rozporządzenia mogły stać się skuteczne w państwie członkowskim, do którego kierowany jest wniosek".

Stosownie do art. 4 ust. 1 rozporządzenia uznawanie środka ochrony wydanego w jednym z państw członkowskich w innych państwach członkowskich następuje bez potrzeby przeprowadzania specjalnej procedury, a jest on wykonalny bez potrzeby stwierdzania jego wykonalności.

Osoba występująca z wnioskiem do właściwego organu państwa, do którego jest on kierowany, powinna - stosownie do ust. 2 art. 4 - dostarczyć temu organowi trzy dokumenty, a mianowicie: a) odpis środka ochrony spełniający warunki niezbędne do stwierdzenia jego autentyczności, b) zaświadczenie wydane w państwie członkowskim wydania środka ochrony oraz c) w razie potrzeby - jego transliterację lub tłumaczenie. Ważne jest przy tym, że dokumenty wydane w państwie członkowskim - jak stanowi art. 15 rozporządzenia - nie wymagają legalizacji albo innych formalności tego rodzaju.

Wskazano, że zaświadczenie jest skuteczne jedynie w granicach wykonalności środka ochrony (art. 4 ust. 3), zaś skutki uznania środka ochrony - niezależnie od czasu jego obowiązywania - trwają najwyżej przez okres 12 miesięcy od czasu wydania zaświadczenia (ust. 4). W pkt 16 Preambuty wyjaśniono w odniesieniu do tej ostatniej regulacji, że „W przypadkach, gdy okres obowiązywania środka ochrony jest dłuższy niż 12 miesięcy, ograniczenie skutków uznania na mocy ... rozporządzenia nie powinno naruszać prawa osoby objętej ochroną do powołania się na ten środek ochrony na podstawie jakiegokolwiek innego dostępnego unijnego aktu prawnego zapewniającego uznawanie ani prawa do ubiegania się o krajowy środek ochrony w państwie członkowskim, do którego kierowany jest wniosek". Dodano jednocześnie (pkt 17 Preambuty), że regulacja ta ma charakter wyjątkowy „ze względu na szczególny charakter ... rozporządzenia, wobec czego 
rozwiązanie to nie powinno być precedensem dla innych instrumentów odnoszących się do spraw cywilnych i handlowych".

Wykonywanie środka ochrony - w myśl art. 4 ust. 5 rozporządzenia - podlega prawu państwa, do którego jest kierowany wniosek.

\subsection{Zaświadczenie}

Szczególnie ważnym dokumentem jest zaświadczenie wydawane na wniosek osoby objętej ochroną przez organ wydający państwa członkowskiego wydania przy użyciu wielojęzycznego standardowego formularza (art. 5 ust. 1). Do opracowania jego wzoru została upoważniona Komisja Europejska (art. 19) ${ }^{13}$. W formularzu ma się znaleźć miejsce na informacje niestandardowe, przy czym „Liczba pól tekstowych przeznaczonych na tekst niestandardowy powinna być ... możliwie najbardziej ograniczona, tak aby w większości przypadków - dzięki wykorzystaniu odpowiedniej wersji językowej ... formularza - można było zapewnić tłumaczenie lub transliterację, nie obciążając osoby objętej ochroną jakimikolwiek kosztami. Wszelkie koszty niezbędnego tłumaczenia wykraczającego poza tekst wielojęzycznego standardowego formularza mają zostać rozdzielone zgodnie z przepisami państwa członkowskiego wydania" (pkt 23 Preambuły). Jednocześnie, jeżeli zaświadczenie zawiera tekst niestandardowy, „właściwy organ państwa członkowskiego, do którego kierowany jest wniosek, ma ustalić, czy wymagane jest jakiekolwiek tłumaczenie lub transliteracja. Nie powinno to wykluczać możliwości zapewnienia tłumaczenia lub transliteracji $\mathrm{z}$ własnej inicjatywy przez osobę objętą ochroną lub organ wydający państwa członkowskiego wydania" (pkt 24 Preambuty).

Generalna reguła dotycząca tłumaczeń jest taka, że dokonuje ich osoba uprawniona do wykonania tej czynności w jednym z państw członkowskich (art. 16 ust. 2). W art. 5 ust. 3 zostało przewidziane odstępstwo od niej polegające na tym, że osoba objęta ochroną ma prawo do wystąpienia do organu wydającego państwa członkowskiego wydania z wnioskiem o dostarczenie jej transliteracji lub tłumaczenia

13 Taki akt wykonawczy - jak dotąd - nie został wydany. 
zaświadczenia na wielojęzycznym standardowym formularzu. Transliteracji lub thumaczenia dokonuje się na język urzędowy albo jeden z takich języków państwa członkowskiego, do którego kierowany jest wniosek, bądź też ,na jakikolwiek inny język urzędowy instytucji Unii, który państwo to wskazało jako możliwy do zaakceptowania" (art. 16 ust. 1).

Ważne jest, że przeciwko wydaniu zaświadczenia nie przysługuje środek zaskarżenia (art. 5 ust. 2).

Stosownie do art. 7 rozporządzenia treść zaświadczenia obejmuje następujące informacje: a) nazwę i adres lub dane kontaktowe organu wydającego; b) numer sprawy; c) datę wydania zaświadczenia; d) dane dotyczące osoby objętej ochroną: imię i nazwisko; datę i miejsce urodzenia, jeżeli są dostępne; adres używany do powiadomień z wyraźnym zastrzeżeniem, że nie może on zostać przekazany osobie stwarzającej zagrożenie; e) dane dotyczące osoby stwarzającej zagrożenie: imię i nazwisko; datę i miejsce urodzenia, jeżeli są dostępne; adres do powiadomień; f) wszystkie informacje niezbędne do wykonania środka ochrony, a w tym, w stosownych przypadkach, rodzaj środka i obowiązek nałożony nim na osobę stwarzającą zagrożenie z określeniem funkcji miejsca lub strefy, do których osobie tej zabroniono zbliżać się lub wchodzić; g) okres obowiązywania środka ochrony; h) czas trwania skutków uznania w myśl przedstawionej już regulacji art. 4 ust. 4; i) oświadczenie o spełnieniu wymogów związanych z wydaniem zaświadczenia określonych $w$ art. 6; j) informacje o prawach do domagania się sprostowania lub uchylenia zaświadczenia, o czym jest mowa w art. 9, jak też do wnioskowania o odmowę uznania lub wykonania środka ochrony na podstawie art. 13; oraz w końcu - k) tytuł rozporządzenia $\mathrm{w}$ jego pełnym brzmieniu.

Przepis art. 6 rozporządzenia powołany w przytoczonym art. 7 lit. i) zastrzega, że zaświadczenie może zostać wydane jedynie pod warunkiem, że osoba stwarzająca zagrożenie została - zgodnie z prawem państwa wydania - powiadomiona o nałożeniu środka ochrony (ust. 1). Jeżeli nastąpiło to zaocznie, zaświadczenie może zostać wydane jedynie wówczas, ,gdy osobie stwarzającej zagrożenie doręczono dokument wszczynający postępowanie lub dokument równoważny 
lub, w stosownych przypadkach, gdy osoba ta została w inny sposób poinformowana o wszczęciu postępowania zgodnie z prawem państwa członkowskiego wydania w odpowiednim czasie i w sposób umożliwiający tej osobie przygotowanie do obrony" (ust. 2). Natomiast w sytuacji, gdy procedura będąca podstawą wydania środka ochrony nie przewiduje uprzedniego powiadomienia osoby stwarzającej zagrożenie, ,zaświadczenie można wydać jedynie pod warunkiem, że osoba ta miała prawo do zaskarżenia tego środka ochrony na mocy prawa państwa członkowskiego wydania" (ust. 3). Tak więc, konieczną przesłanką umożliwiającą wydanie zaświadczenia jest - najogólniej - to, aby osoba stwarzająca zagrożenie wiedziała o nałożeniu na nią środka lub środków ochrony objętych rozporządzeniem. Wiąże się to z zapewnieniem przestrzegania prawa do obrony, które przysługuje osobie stwarzającej zagrożenie wówczas, gdy środek ochrony został wydany zaocznie lub w ramach procedury nieprzewidującej jej uprzedniego powiadamiania. W takich przypadkach ,wydanie zaświadczenia powinno być możliwe wyłącznie, jeśli osoba ta miała możliwość zapewnienia sobie obrony przed środkiem ochrony. Jednak aby zapobiec obchodzeniu przepisów oraz z uwagi na pilny zazwyczaj charakter spraw wymagających zastosowania środków ochrony, nie powinno być wymagane, aby termin do obrony upłynął przed wydaniem zaświadczenia. Zaświadczenie powinno zostać wydane niezwłocznie po tym, jak środek ochrony stanie się wykonalny w państwie członkowskim wydania" (pkt 25 Preambuty).

Z kolei stosownie do unormowań pierwszego z przepisów wskazanych w art. 7 lit. j) rozporządzenia, czyli art. 9, zarówno osoba objęta ochroną, jak i osoba stwarzająca zagrożenie mogą wnioskować, aby organ wydający państwa członkowskiego wydania dokonał sprostowania zaświadczenia w przypadku, gdy ze względu na błąd pisarski powstała rozbieżność między środkiem ochrony i zaświadczeniem, bądź też uchylił zaświadczenie wówczas, gdy „w sposób oczywisty” wydane zostało z naruszeniem zasad przewidzianych w rozporządzeniu (ust. 1). Postępowanie w takich sprawach toczy się według prawa państwa, w którym zaświadczenie zostało wydane (ust. 2). 
Natomiast w myśl art. 13, drugiego z wymienionych w art. 7 lit. j) przepisów rozporządzenia, osoba stwarzająca zagrożenie ma prawo złożyć wniosek o odmowę uznania i - w stosownych przypadkach wykonania środka ochrony w takim zakresie, w jakim uznanie byłoby wyraźnie sprzeczne z porządkiem publicznym państwa członkowskiego, do którego kierowany jest wniosek, bądź też nie do pogodzenia $\mathrm{z}$ wydanym lub uznanym w nim wyrokiem (ust. 1).

\subsection{Powiadomienie osoby stwarzającej zagrożenie}

Osoba stwarzająca zagrożenie musi zostać poinformowana nie tylko o nałożonym na nią środku ochrony, o czym była już mowa, ale również o wydaniu zaświadczenia oraz o tym, że fakt ten skutkuje jego uznaniem $\mathrm{i}$ - w stosownych przypadkach - wykonalnością środka ochrony we wszystkich państwach członkowskich (art. 8 ust. 1).

Zasady dotyczące powiadamiania są następujące: a) jeżeli osoba ta zamieszkuje w państwie członkowskim wydania - obowiązuje w tym zakresie prawo tego państwa (art. 8 ust. 2 akapit 1, zd. 1); b) jeżeli zamieszkuje $\mathrm{w}$ innym państwie członkowskim lub w państwie trzecim - powiadomienia dokonuje się listem poleconym lub w podobny równoważny sposób (art. 8 ust. 2, akapit 1, zd. 2); c) jeżeli jej adres nie jest znany lub odmawia ona odebrania powiadomienia - zgodnie z prawem państwa członkowskiego wydania (art. 8 ust. 2 akapit 2).

\subsection{Ochrona prywatności}

Przepis art. 8 ust. 3. rozporządzenia wskazuje na konieczność ochrony prywatności ofiar. Stanowi on, że „Miejsce pobytu lub inne dane kontaktowe osoby objętej ochroną nie mogą być ujawniane osobie stwarzającej zagrożenie, chyba że ich ujawnienie jest niezbędne do zapewnienia przestrzegania lub wykonania środka ochrony". Również w Preambule (pkt 27) podniesiono, iż w tym przypadku, podobnie jak ,,przy jakimkolwiek dostosowywaniu środka ochrony w państwie członkowskim, do którego kierowany jest wniosek, należy zwrócić należytą uwagę na to, że w interesie osoby objętej ochroną leży nieujawnianie miejsca jej pobytu lub innych danych kontaktowych. Danych takich nie należy 
ujawniać osobie stwarzającej zagrożenie, chyba że takie ujawnienie jest niezbędne ...". Wyrazem dbałości o ochronę prywatności ofiar jest też zastrzeżenie zamieszczone we wzorach standardowych formularzy. Dodać trzeba, że zasady ochrony prywatności ofiar są w tym przypadku takie same jak przewidziane w odniesieniu do ENO.

Przytoczone zapisy zostały wprowadzone do rozporządzenia dopiero dzięki uwzględnieniu uwag Europejskiego Inspektora Ochrony Danych przedstawionych w jego opinii z dnia 17 października 2011 r. (pkt 30) ${ }^{14}$. Nie odwołano się natomiast, co sugerował on także, do dyrektywy Parlamentu Europejskiego i Rady 95/46/WE z dnia 24 października 1995 r. w sprawie ochrony osób fizycznych w zakresie przetwarzania danych osobowych i swobodnego przepływu tych danych ${ }^{15}$, która ma jednak charakter ogólny i nie zawiera postanowień odnoszących się do ofiar jako szczególnej kategorii podmiotów danych ${ }^{16}$.

\subsection{Pomoc dla osoby objętej ochroną}

Organ wydający państwa wydania - na wniosek ofiary - „udziela jej pomocy w uzyskaniu udostępnianych zgodnie z art. 17 i 18 informacji dotyczących organów państwa członkowskiego, do którego kierowany jest wniosek, przed którymi należy powoływać się na środek ochrony lub występować o jego wykonanie" (art. 10 rozporządzenia).

Stosownie do art. 17 państwa członkowskie „W ramach europejskiej sieci sądowej w sprawach cywilnych i handlowych... ${ }^{17}$ oraz z myślą

14 Opinia w sprawie pakietu legislacyjnego dotyczącego praw ofiar przestępstw, w tym wniosku dotyczącego dyrektywy ustanawiającej normy minimalne w zakresie praw, wsparcia i ochrony ofiar przestępstw oraz wniosku dotyczącego rozporządzenia w sprawie wzajemnego uznawania środków ochrony w sprawach cywilnych $(2012 / \mathrm{C}$ 35/02), Dz. Urz. UE C 35 z 9.2.2012, s. 10.

15 Dz.Urz. WE L 281 z 23.11.1995, s. 31.

16 Szerzej: E. BIEŃKOWSKA, Europejskie standardy ochrony prywatności ofiar przestepstw, «Prokuratura i Prawo»9/2013, s. 5 i n.; TEJżE, Ochrona danych osobowych $i$ wizerunku ofiar przestepstw w Unii Europejskiej, [w:] Ochrona danych osobowych $i$ wizerunku ofiar przestępstw, pod. red. L. Mazowieckiej, Warszawa 2014, s. 37 i n.

17 Zob. decyzję Rady z dnia 28 maja 2001 r. ustanawiającą Europejską Sieć Sądową w sprawach cywilnych i handlowych (2001/470/WE), (Dz.Urz.WE L 174 
o publicznym udostępnianiu informacji, dostarczają opis krajowych przepisów i procedur dotyczących środków ochrony w sprawach cywilnych, w tym informacje o rodzaju organów właściwych w sprawach objętych zakresem stosowania ... rozporządzenia".

W konsekwencji - na mocy art. 18 ust. 1 - na państwa członkowskie został nałożony obowiązek przekazania Komisji w terminie do dnia 11 lipca 2014 r. informacji o: a) organach właściwych w sprawach, o których mowa w rozporządzeniu ze wskazaniem: (i) właściwych do wydawania środków ochrony i zaświadczeń zgodnie z art. 5; (ii) przed którymi należy się powoływać na środek ochrony wydany w innym państwie członkowskim lub które są właściwe do jego wykonania; (iii) które są właściwe do dostosowania środka ochrony zgodnie z art. 11 ust. 1; jak również (iv) sądach, ,do których należy wystąpić z wnioskiem o odmowę uznania oraz, w stosownych przypadkach, o odmowę wykonania zgodnie $\mathrm{z}$ art. 13; oraz b) języku lub językach akceptowanych w tłumaczeniach w myśl art. 16 ust. 1.

Komisja udostępnia publicznie wskazane informacje ,przy użyciu wszelkich właściwych środków, w szczególności poprzez stronę internetową europejskiej sieci sądowej ..." (art. 18 ust. 2). W pkt 35 zd. 2 Preambuły wskazano, iż dostęp do informacji przekazywanych przez państwa członkowskie ma być możliwy za pośrednictwem europejskiego portalu „Sprawiedliwość”.

\subsection{Dostosowanie środka ochrony}

Bardzo ważne jest unormowanie art. 13 ust. 3 rozporządzenia, w myśl którego podstawą odmowy uznania środka ochrony nie może być to, że prawo państwa członkowskiego, do którego kierowany jest wniosek, nie przewiduje stosowania takiego środka w analogicznych okolicznościach. Rozporządzenie nie obliguje jednak do zmiany krajowych systemów prawnych mającej na celu umożliwienie wydawania środków ochrony w sprawach cywilnych ani do ich wprowadzania dla potrzeb jego stosowania (pkt 12 zd. 2 Preambuty). Określa natomiast

z 27.6.2001, s. 25) zm. decyzją Parlamentu Europejskiego i Rady 568/2009/WE z dnia 18 czerwca 2009 r., Dz.Urz.WE L 168 z 30.6.2009, s. 35. 
reguły dotyczące procedury dostosowania elementów faktycznych środka ochrony przez właściwy organ państwa, do którego kierowany jest wniosek, stosownie do jego prawa wewnętrznego (art. 11 ust. 2).

Dostosowanie środka ochrony ma mieć miejsce jedynie $\mathrm{w}$ razie konieczności oraz w niezbędnym zakresie tak, aby nadać danemu środkowi skuteczność w państwie, do którego kierowany jest wniosek (art. 11 ust. 1). Podkreślić jednak należy, iż w państwie tym w żadnym przypadku nie jest dopuszczalna kontrola merytoryczna środka ochrony wydanego w państwie członkowskim wydania (art. 12).

O dostosowaniu środka ochrony powiadamia się osobę stwarzającą zagrożenie, a obowiązują w tym względzie zasady, o których jest mowa w art. 11 ust. 3-6 rozporządzenia, takie same, jak - opisane już wcześniej - odnoszące się do powiadamiania jej o wydaniu zaświadczenia w myśl art. 8 ust. 2.

\subsection{Zawieszenie lub uchylenie uznania lub wykonania}

Stosownie do art. 14 ust. 1 rozporządzenia w trzech sytuacjach organ wydający państwa członkowskiego wydania - na wniosek osoby objętej ochroną lub osoby stwarzającej zagrożenie - wydaje zaświadczenie potwierdzające zawieszenie, ograniczenie lub uchylenie środka ochrony przy użyciu wielojęzycznego standardowego formularza opracowanego przez Komisję Europejską ${ }^{18}$. Ma to miejsce wówczas, gdy zostaje on zawieszony lub uchylony w tym państwie albo zostaje zawieszona lub ograniczona jego wykonalność, bądź też zaświadczenie zostaje uchylone w związku z wydaniem go w sposób oczywiście nieprawidłowy w myśl art. 9 ust. 1 lit. b) rozporządzenia.

Po przedstawieniu przez osobę objętą ochroną lub osobę stwarzającą zagrożenie wskazanego zaświadczenia właściwy organ państwa członkowskiego, do którego kierowany jest wniosek, zawiesza lub uchyla skutki uznania oraz - w stosownym przypadku - zawiesza lub uchyla wykonanie środka ochrony (art. 14 ust. 2).

18 Komisja Europejska nie wydała jeszcze aktu wykonawczego z wzorem takiego formularza. 


\section{UWAGI KOŃCOWE}

Jak syntetycznie ujął to J. Pisuliński, „Rozporządzenie nr 606/2013 reguluje automatyczne uznawanie w innych państwach członkowskich środków ochrony przyznanych osobie fizycznej, której integralność fizyczna lub psychiczna może być zagrożona, a polegających np. na zakazie lub ograniczeniu wstępu do miejsca zamieszkania lub pracy tej osoby czy kontaktów z nią ... . W państwie członkowskim podejmowane są działania konieczne w celu dostosowania tych środków, aby mogły być skuteczne w tym państwie (art. 11 rozporządzenia). Odmowa uznania lub wykonania przyznanych środków ochrony dopuszczalna jest jedynie wyjątkowo w sytuacjach określonych w art. 13 rozporządzenia"19. Nie może jednak - co trzeba bardzo mocno podkreślić - stanowić takiej podstawy fakt, że prawo państwa, do którego kierowany jest wniosek, nie przewiduje danego środka ochrony.

Polskie prawo zna jeden środek ochrony o charakterze cywilnym. Jest nim - przewidziane w art. 11a ustawy z dnia 29 lipca 2005 r. o przeciwdziałaniu przemocy w rodzinie ${ }^{20}$ - żądanie przez osobę dotkniętą przemocą w rodzinie, aby sąd zobowiązał do opuszczenia mieszkania wspólnie zamieszkującego członka rodziny, który swoim zachowaniem polegającym na stosowaniu takiej przemocy czyni wspólne zamieszkiwanie szczególnie uciążliwym. Jak już jednak pisałam, rozporządzenie nr 606/2013 ostatecznie nie objęło takiego środka ochrony.

Jest to równoznaczne z tym, że jego skutki będą miały wyłącznie charakter jednokierunkowy. Polska, nie mogąc być krajem wydania danego środka, lecz jedynie krajem, do którego kierowany jest wniosek, będzie zobowiązana do uznania $\mathrm{i}$ - w odpowiednich przypadkach - do wykonania uwzględnionych w nim środków ochrony ofiary zastosowanych w innych państwach unijnych. Nie zapewni natomiast rodzimym ofiarom przewidzianej w rozporządzeniu ochrony w sytuacjach transgranicznych. Tak, jak bowiem nie są one takimi środkami

19 J. PisUlińSKi, op. cit., s. 25.

20 Dz.U. Nr 180, poz. 1493 ze zm. 
chronione w Polsce, tak też nie będą mogły być chronione w innych państwach członkowskich Unii Europejskiej.

$\mathrm{Z}$ tego punktu widzenia korzystniejszym instrumentem ochrony, mimo wszelkich jego mankamentów, jest ENO. Wynika to stąd, że polskie prawo przewiduje nakazy i ograniczenia stanowiące odpowiedniki środków wymienionych w art. 5 dyrektywy 2011/99/UE jako mogące łączyć się ze środkiem zapobiegawczym w postaci dozoru (art. 275 § 2 k.p.k.) oraz będące środkami karnymi (art. 39 pkt 2b k.k.) lub środkami probacyjnymi (art. $72 \S 1$ pkt 7 i 7a k.k.). Oznacza to, że ofiary przestępstw mogą ubiegać się w Polsce o wydanie ENO, a ofiary pochodzące $\mathrm{z}$ innych państw członkowskich - o jego uznanie i wykonanie. W dużej mierze środki takie znane są bowiem w pozostałych państwach unijnych, co z kolei pozwala także na uznanie i wykonanie w nich ENO uzyskanego w Polsce.

\section{Mutual Recognition of Protection Measures in Civil Matters}

Summary

The paper describes the latest EU law concerning the enhancement of the rights of victims, i.e. Regulation (EU) No 606/2013 of the European Parliament and of the Council of 12 June 2013 on mutual recognition of protection measures in civil matters. In the Polish legal system there are no analogous measures, which means that the residents of Poland cannot be protected in trans-border situations unless the law is amended.

Słowa kluczowe: prawa ofiar przestępstw, europejski nakaz ochrony (ENO)

Keywords: rights of victims, European Protection Order 